\title{
Insuring against Neighboring Crises : International Reserves in Latin America
}

\author{
Luis D. Rosero \\ Framingham State University, Framingham, USA
}

\begin{abstract}
This paper revisits the traditional literature on optimal demand for international reserves by exploring the possibility that perceived contagion risk originating from neighboring countries influences a country's own demand for reserves. In addition, it highlights another reason why the mechanisms of local coordination and support within the framework of regional integration might be desirable additions to the current international financial structure. Using a sample of the seven largest Latin American economies, the empirical evidence presented here suggests that countries take into consideration the volatility conditions of their neighbors when determining their own optimal level of reserves. Moreover, given that countries in Latin America appear to purchase insurance against contagion risk, this paper argues that a mechanism of reserve pooling that increases the protection of all members of the pool might reduce the risk of contagion and thereby also reduce the opportunity cost faced by individual countries.
\end{abstract}

JEL Classifications: F33, F34, F36

Keywords: International Reserves, Contagion, Regional Integration, Reserve Pooling

\footnotetext{
* Corresponding Author: Luis D. Rosero; Economics Department, Framingham State University, 100 State Street, Framingham, MA, USA; Tel: +1 5082155716, E-mail: 1rosero@framingham.edu.
} 


\section{Introduction}

One of the defining trends in international finance of the last two decades has been the unprecedented growth in the levels of international reserves accumulated by emerging nations. International reserves held by developing countries in 2013 were nearly 38 times larger than that of 1990. In a global financial system characterized by market failures and sudden stops, many developing countries have opted for the protection provided by the individual accumulation of reserves as a second-best outcome. However, as suggested by Rodrik (2006), the accumulation of reserves comes at a hefty (social) opportunity cost to the nations that hold them. It is this particular aspect that brings into question - or at least merits a re-examination of - the validity and efficiency of reserve accumulation as a stabilization and development strategy, particularly in the context of some cash-strapped developing nations.

A concurrent trend, and a direct response to this dilemma, has been the push for the creation of regional arrangements of cooperation and integration throughout the developing world. Arguments in favor of these mechanisms have ranged from pure political and cultural ties to the benefits of risk-sharing and macro coordination. An important category of these regional mechanisms has involved the establishment of reserve pooling and foreign exchange swap arrangements. Institutions like the Latin American Reserve Fund (FLAR) and the Chiang Mai Initiative (CMI) in South East Asia have gained a new impetus in recent years. Moreover, these institutions have become an important component of the International Monetary Fund's more recent attempt to reshape itself to better deal with the global imbalances problem and with the muchneeded democratization of the fund. In a speech about the future of the International Monetary Fund (IMF), its then Managing Director, Dominique Strauss-Kahn (2010), had this to say about the role of regional reserve pooling arrangements:

“...we might look at ways to collaborate with regional reserve pools. We certainly do not see such funds as 'competitors.' Indeed, they can be a positive and stabilizing force in international financing - as exemplified by recent European Union lending in parallel with Fund programs. Such collaboration could even include Fund resources serving as a backstop to regional pools."

The literature on the demand for international reserves has addressed many of the 
key issues with respect to the motive, size adequacy, and potential alternatives to the current framework of reserve accumulation. However, given the extensive evidence of the prevalence of crisis contagion tendencies among emerging market countries, the literature could still benefit from exploring the linkage between the optimal reserve demand decision and the potential risk associated with contagion. Traditional models of reserve demand have mostly adopted a country-specific approach under which the optimal reserve demand function is determined partially in a vacuum. The degree to which this decision is made based on external conditions, particularly those of neighboring countries, should be further considered.

This paper addresses the nexus between international reserve accumulation and the prevalence of contagion in Latin America by first identifying to what degree countries in the region are accounting for the level of financial distress in neighboring countries when setting their own demand for reserves, if at all. In order to accomplish this task, a proxy for perceived contagion risk is first constructed based on previous models of exchange rate market pressure. Using cross-sectional time series data for the seven largest economies in Latin America and least squares estimation techniques, this paper empirically identifies a significant positive effect of perceived contagion risk on the growth rate of the accumulation of reserves. These countries were chosen because together they represent the core of the Latin American economy, accounting for almost $91 \%$ of the region's gross domestic product, and $88.5 \%$ of its total external debt in 2013 (CEPALStat 2014). Thus, the financial stability of the region is largely determined by the performance of the considered countries comprising of Argentina, Brazil, Chile, Colombia, Mexico, Peru, and Venezuela.

Additionally, this paper places the effects of insuring against perceived contagion risk in context, by estimating the cost of this additional level of insurance. Moreover, it concludes with an exploration of the increased insurance coverage that may ensue from reductions in the countries' variability in the balance of payments. This decrease in variability is based on the premise that regional reserve pools reduce contagion risk, which in turn leads to a more stable balance of payments. Simplified simulations based on different hypothetical levels of reduced variability are considered to calculate potential increases in insurance coverage.

The empirical identification of the role of contagion risk in the optimal demand for reserves has important policy implications. Latin American monetary authorities, to the extent that they are looking to maintain a comparable level of protection against sudden stops, real market shocks, and to reduce the opportunity cost of holding reserves, should 
give some consideration to alternative strategies to the current model of self-insurance. This paper finds that the opportunity cost of the precautionary accumulation of reserves to deal with contagion risk is not negligible. Thus, as previously argued by others in the literature and as illustrated in the last section of this paper, countercyclical policies like regional reserve pooling, through a reduction in contagion risk and balance of payment volatility, can lead to significant efficiency gains in the optimal reserve accumulation process. It is important to note, however, that the regional pooling of international reserves is only one of several methods of improving the efficiency of precautionary reserve accumulation.

The remainder of this paper is as follows. The next section provides some background on reserve accumulation in Latin America. Section III explores the literature on optimal reserve demand, contagion, and reserve pooling. Section IV develops a proxy variable for perceived contagion risk, which is then used to empirically extend the traditional Buffer Stock Model. This section also details the methods used to estimate the potential gains from reserve pooling. Section V presents the empirical findings. Section VI concludes.

\section{Background}

If not at the same level observed in East Asia, the accumulation of reserves in Latin America has dramatically increased in recent years. This positive trend, which appears to start at the turn of the century, continued uninterrupted until recently, with the exception of the second half of 2008 when the effects of the global financial crisis reached the region. Once the Great Recession ended, the positive growth in the accumulation of international reserves by most Latin American countries resumed. The aggregate reserves of the seven largest Latin American countries (Argentina, Brazil, Chile, Colombia, Mexico, Peru, and Venezuela) reached 714 billion US dollars in the fourth quarter of 2013, which is a significant figure by most standards. Among these countries, Brazil, Mexico, Colombia, and Peru experienced the most dramatic increase, while Venezuela saw its reserves increase at a more moderate rate, including a considerable drawdown in the last couple of years as it can be seen from Figure 1 and Table 1. 
Figure 1. Latin American non-gold foreign reserves

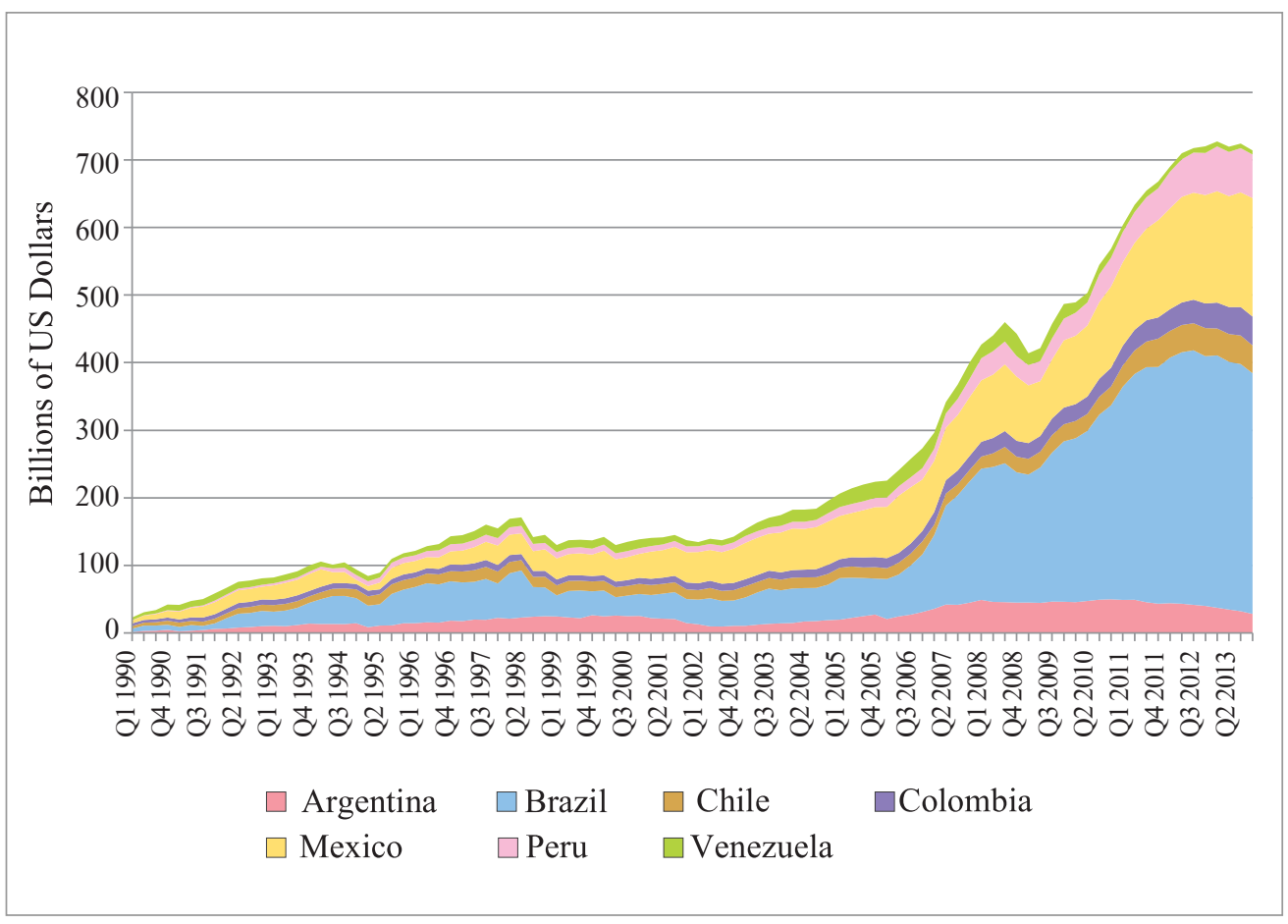

(Source) IMF, International Financial Statistics.

Table 1. Average non-gold international reserves

$(1970=1)$

\begin{tabular}{|l|c|c|c|c|c|c|c|}
\hline & $\mathbf{1 9 7 0 ~ 1 9 7 9}$ & $\mathbf{1 9 8 0} \mathbf{1 9 8 9}$ & $\mathbf{1 9 9 0} \mathbf{1 9 9 4}$ & $\mathbf{1 9 9 5} \mathbf{1 9 9 9}$ & $\mathbf{2 0 0 0 \sim 2 0 0 4}$ & $\mathbf{2 0 0 5} \mathbf{2 0 0 9}$ & $\mathbf{2 0 1 0 \sim 2 0 1 3}$ \\
\hline Argentina & 4.24 & 5.13 & 18.29 & 39.70 & 31.25 & 72.75 & 75.59 \\
\hline Brazil & 4.99 & 6.08 & 18.51 & 41.47 & 36.22 & 131.04 & 298.51 \\
\hline Chile & 1.37 & 7.78 & 26.33 & 45.15 & 44.81 & 59.40 & 111.52 \\
\hline Colombia & 5.91 & 16.36 & 36.84 & 47.24 & 57.10 & 104.81 & 182.95 \\
\hline Mexico & 2.26 & 9.45 & 27.43 & 45.29 & 89.40 & 152.14 & 264.08 \\
\hline Peru & 1.87 & 4.30 & 11.29 & 32.45 & 32.63 & 80.65 & 182.75 \\
\hline Venezuela, RB & 7.64 & 10.64 & 14.40 & 17.80 & 20.49 & 41.58 & 15.32 \\
\hline
\end{tabular}

(Note) 1970 is the base year.

(Source) Calculations based on World Bank, World Development Indicators. 
The growth in reserves goes beyond its nominal level considerations, and is also evident in terms of the countries' short-term debt which is a critical variable when considering the precautionary role of reserves. The region overall has steadily increased its ratio of international reserves to short-term debt in the last four decades, with all of the countries in the sample having ratios in excess of one by the end of 2013 as it can be seen in Table 2. In contrast, as recent as the first half of the 1990s, only two of the countries considered, Colombia and Venezuela, had reserves exceeding their short-term debt. This ratio is significant not only because it serves as a strong signal of a country's ability to meet its debt obligations in the upcoming year, but also because this measure is being explicitly used by country officials as part of the management process of their reserves (IMF 2001). Accelerated efforts to increase foreign reserve holdings following the Asian Financial Crisis, along with a conscious attempt at restructuring the external debt in favor of longer term commitments, have reduced the apparent vulnerability of the region, at least in terms of meeting its short-term debt obligations. Thus by 2013, countries like Brazil and Peru found themselves in a position to potentially cover around seven times their short-term debt requirements by using their accumulated international reserves. Moreover, it is important to note that according to the widely-cited GuidottiGreenspan rule of reserve adequacy (Greenspan 1999) ${ }^{1}$; all countries in the sample hold massive excess reserves.

Table 2. Ratio of total reserves to short-term debt

\begin{tabular}{|l|c|c|c|c|c|c|c|}
\hline & $\mathbf{1 9 7 2} \mathbf{1 9 7 9}$ & $\mathbf{1 9 8 0} \mathbf{1 9 8 9}$ & $\mathbf{1 9 9 0} \mathbf{1 9 9 4}$ & $\mathbf{1 9 9 5} \mathbf{1 9 9 9}$ & $\mathbf{2 0 0 0} \mathbf{2 0 0 4}$ & $\mathbf{2 0 0 5} \mathbf{2 0 0 9}$ & $\mathbf{2 0 1 0 ~ 2 0 1 2}$ \\
\hline Argentina & 1.42 & 0.46 & 0.84 & 0.79 & 0.73 & 1.48 & 3.15 \\
\hline Brazil & 1.68 & 0.51 & 0.59 & 1.48 & 1.51 & 3.98 & 6.91 \\
\hline Colombia & 0.80 & 1.40 & 2.66 & 1.65 & 2.97 & 3.66 & 3.32 \\
\hline Mexico & 0.56 & 0.32 & 0.43 & 0.80 & 2.46 & 3.26 & 2.73 \\
\hline Peru & 0.50 & 0.62 & 0.65 & 1.46 & 3.29 & 5.50 & 7.37 \\
\hline Venezuela, RB & 2.33 & 1.28 & 3.71 & 2.48 & 2.06 & 2.28 & 1.47 \\
\hline Latin America \& Caribbean & 1.52 & 0.72 & 0.88 & 1.21 & 1.70 & 3.02 & 4.13 \\
\hline
\end{tabular}

(Source) Calculations based on World Bank, World Development Indicators.

${ }^{1}$ This rule of thumb states that countries should hold levels of reserves equal to their short-term external debt. 


\section{Literature Review}

\section{A. Optimal reserve demand}

The economics literature on the demand for international reserves can be loosely divided into reserve accumulation driven by mercantilist and precautionary motives. ${ }^{2}$ Proponents of the mercantilist approach to reserve demand argue that the recent accumulation of reserves by developing countries can be best explained by conscious efforts by their monetary authorities to maintain an undervalued currency, and thereby increase the competitiveness of their exporting industries (Dooley et al. 2005). Evidence from the case of China - with reserves exceeding 3.8 trillion US dollars by the end of 2013 and an arguably undervalued Renminbi - seems to give some validity to this view.

On the other hand, the precautionary view of reserve accumulation is based on the idea that countries accumulate savings in the form of reserves to deal with the uncertainties that may arise from sudden-stop episodes and other balance of payments shocks. This approach remains the focus of the reserve demand literature, and as such, it has closely resembled the main tenets of the quantity theory of money. From the precautionary point of view, reserves are seen to serve three critical roles: (i) provision of liquidity during shocks to the balance of payments, or during national emergencies, (ii) reduction in adjustment costs following a crisis, and (iii) boosting confidence in the finances of the local economy, thus contributing to the deterrence of potential speculative attacks.

Cooper (1968) highlights the role of reserves in providing short-term policy space to countries facing balance of payment shocks, thus reducing and/or delaying the implementation of painful expenditure switching and expenditure reduction measures. Financial crises in developing countries tend to be accompanied by costly disruptions to their economies, such as low or negative economic growth, growing unemployment rates, declining terms of trade, and deterioration in the debt structure. Thus, reserves are seen as a countercyclical buffer aimed at minimizing the potential damage to the domestic economy, either by deterring a crisis from happening or by alleviating the

\footnotetext{
${ }^{2}$ More recently, some in the literature have argued that the recent unprecedented accumulation of reserves by developing countries is the result of a keeping up with the Joneses effect (Cheung and Sengupta 2011). However, this desire for conspicuous consumption of reserves can arguably be partly understood as being motivated by precautionary measures (i.e., not wanting to be left behind and being perceived as less stable).
} 
negative consequences when one does occur.

However, along with these important benefits, there is a significant opportunity cost attached that must also be considered when demanding foreign reserves. By their precautionary nature, foreign reserves are typically in the form of safe and very liquid assets, e.g., the US Treasury securities, with corresponding low yields. In the meantime, many Latin American countries are increasingly relying on international financial markets for the financing of their public and private economic activities by issuing relatively high yield securities. The gap between the yield structures of the assets and liabilities held by developing countries' central banks accounts for the opportunity cost of reserves. ${ }^{3}$ Heller (1966) first provided a model based on a cost minimization problem, where the monetary authorities select an optimal level of reserves to minimize the costs (adjustment and opportunity costs) that may arise from a crisis event. While the concept of opportunity cost within the context of reserve demand was first introduced by Heller (1966), it was Frenkel and Jovanovic (1981) who, building upon this work, developed the Buffer Stock model. This model, which to this day provides the basic framework for most empirical studies of reserve demand (including this one), directly reflects the maximization problem stated above.

There appears to be some consensus in the literature that foreign reserve demand by Latin American countries is more in line with the traditional precautionary motive first advanced by Heller (1966). Aizenman and Lee (2007) and Perez (2009) argue that the empirical evidence for Latin America does not support the idea that reserve accumulation in the region is primarily the result of exchange rate manipulations, which would be in keeping with the mercantilist approach. With that in mind, the remainder of this paper will concentrate on the treatment of reserve accumulation from the viewpoint of insurance protection against potentially costly crisis events, without entirely dismissing potential mercantilist reasons. In any event, mercantilist reasons can arguably be subsumed under the precautionary motive if one assumes that the sustainability of a stable and positive current account would help avert some of the crises previously mentioned.

${ }^{3}$ Bahmani-Oskooee and Brown (2002) provide an extensive review of the literature of optimal reserve demand. 


\section{B. Contagion risk and the precautionary motive}

In order to test this perceived contagion risk as an explanatory variable on the demand for reserves, it is important to first consider the separate, but extensive, literature on contagion. This paper aims to explore the relationship between perceived contagion risk and the optimal reserve accumulation decision from a precautionary motive point of view. In particular, it seeks to account for the effects that the perceived risk of contagion (mainly originating from neighboring countries' distress) may have on the level of the accumulation of reserves of each country. Unlike the first generation crises of the 1980s in Latin America, which can be directly traced back to the financial decisions of individual countries, contagion crises can occur regardless of the strong state of a country's own fundamentals. Thus, this paper aims to account for the effects of the perceived risk associated with contagion crises by endogenizing it into the traditional specification of the Buffer Stock Model proposed by Frenkel and Jovanovic (1981).

In its coarsest form, contagion in the context of financial crisis has come to be understood as a domino effect under which even relatively healthy economies can face painful crisis episodes resulting from economic shocks in other economies, in many cases regardless of their own fundamentals. Forbes and Rigobon (2001) classify the literature on the propagation of shocks into crisis-contingent and non-crisis-contingent theories. The first set of theories is in accordance with the shift-contagion approach, and consists in the transmission of crisis shocks through mechanisms that result in a structural change in the relationship between the affected countries. ${ }^{4}$ As such, they represent a new method of crisis transmission, which does not exist before the onset of the crisis. The second set encompasses all theories in which a crisis is not necessary for the shock transmission process to take place. Thus, this set of theories is in line with what Forbes and Rigobon (2001) described as interdependence. The channels of transmission remain constant with or without the occurrence of a crisis episode. ${ }^{5}$

While these categorizations are important, for the purposes of this paper the perception of contagion risk, whether it originates from either shift-contagion or from interdependence, is bound to lead individual countries to seek protection to minimize the costs associated with the materialization of contagion. Moreover, as argued by Machinea

\footnotetext{
${ }^{4}$ These mechanisms include multiple equilibria (i.e., investor psychology), endogenous liquidity (i.e., reduced liquidity leading to portfolio re-composition), and political contagion (i.e., changes in fixed exchange rate regimes as a result of changes in other countries).

${ }^{5}$ These channels include trade (e.g., devaluations), policy coordination, re-evaluation/learning by investors (i.e., application of lessons learned in one country to another similar country), and random aggregate/global (exogenous) shocks (e.g., a rise in the international interest rate).
} 
and Rozenwurcel (2006), the information asymmetries and herding behavior that characterize shift-contagion also tend to intensify the interdependence among countries in the region.

The existing literature on contagion (under alternative definitions and measurements) provides ample empirical evidence for the prevalence of this phenomenon. For example, using panel quarterly data for twenty industrialized countries, Eichengreen et al. (1996) address the question "by how much does the probability of a currency crisis taking place in a country $i$ in period t change as a result of the presence of a currency crisis in a different country $j$ at time $t$ ?" Even after several checks for sensitivity analysis, they conclude that "... a speculative attack elsewhere in the world is associated with an increased probability of a domestic currency crisis by around eight percentage points."

Studies have also found evidence for the Latin American region in particular. Calvo and Reinhart (1996) conclude that capital flows to four small Latin American countries depend on standard determinants and a contagion proxy, consisting of the capital flows to four large countries in the region. Moreover, using data for weekly stock market returns for selected Latin American and Asian countries, they find that correlation coefficients increased among Latin American countries and decreased between Latin American and Asian countries following the December 1994 Mexican peso devaluation. The authors conclude that this finding provides further evidence that contagion is highly regional in nature. Similarly, Glick and Rose (1999) claim that the trade linkages and patterns that prevail in a region due to geographic proximity are important in propagating a crisis, and they consequently contribute to contagion propagation at the regional level. Kaminsky and Reinhart (1999) find that the conditional probability of a crisis in a Latin American country (when one or several other Latin American countries already face a crisis) is as high as 78\%. Burki and Edwards (1996) looked at contagion in Argentina, Brazil, Chile, Colombia, and Venezuela as a result of the Mexican crisis, and found that contagion was present, but selective. More recently, Basnet and Sharma (2013), in a study of the same seven largest Latin American countries considered in this paper, found high levels of synchronicity among key macroeconomic variables in both the short-run and the longrun for the region. This co-movement highlights the increased risk for contagion, but it also provides fertile ground for macroeconomic regional cooperation. 


\section{Reserve pooling}

The events that surrounded the Asian Financial Crisis of the late 1990s, including the prevalence of contagion, showed that the current international financial institutions and the overall global financial structure remain inadequately designed to address the hazards of globalization that afflict developing nations. ${ }^{6}$ Consequently, along with the exorbitant growth in the accumulation of reserves, many developing countries have opted for the promotion of alternative arrangements of coordination and balance of payments support at the regional level. Some of these mechanisms range from simple bilateral swap arrangements of hard currency (e.g., the Chiang Mai Initiative) to more formal pooling of foreign reserves. In the Latin American context, the well-established Latin American Reserve Fund (FLAR), and to a lesser degree the proposal for the Bank of the South (BOS), exemplify the continuous push for the regionalization of the reserve accumulation process (Rosero and Erten 2010).

Some in the literature, while supportive of the tenets of regional cooperation, have expressed valid reservations about the feasibility of reserve pooling mechanisms in Latin America. For example, Machinea and Rozenwurcel (2006) argue that regional cooperation in the region (including reserve pooling) faces significant obstacles. Chiefly among them is the relative lack to the European Union of existing interdependence as manifested by the low levels of intraregional trade and financial links, as well as the tendency of Latin American countries to try to differentiate themselves from their neighbors following a crisis - in an attempt to avoid being bunched together by unknowledgeable investors. For the case of the FLAR, Eichengreen (2007) concludes that in order for this reserve pool to effectively serve as a lender of last resort during the occurrence of sudden stops, it must overcome key challenges like the loss of insurance coverage for some countries that would ensue from the pooling of reserves among lowvariability and high-variability countries. Consequently, he argues that the FLAR's resources would be better utilized to purchase "contingent debt securities issued by Latin American governments and corporations: domestic-currency inflation-indexed bonds, GDP-indexed bonds, and commodity-price-indexed bonds."

Notwithstanding these concerns, and as shown by the recent interest of the IMF in the concept (Strauss-Kahn 2010), there is support in the literature for the creation of mechanisms of regional integration that promote policy coordination and support like

\footnotetext{
${ }^{6}$ Ocampo (2000) and Stiglitz (2002) provide an extensive treatment of this view.
} 
reserve pooling. The rationalization for the creation of these mechanisms has been based on principles well-summarized in Ocampo (2006), among others. For instance, according to Ocampo, the rise of open regionalism that has accompanied globalization has intensified the degree at which externalities from the macroeconomic policies of one country can affect its neighbors in the area. Thus, in line with arguments presented in this paper, he states that policies that only address the problems of an individual country (while ignoring the effects on its neighbors) are likely to make contagion more likely, for example through reduced regional trade and competitive devaluations. Moreover, he argues that as globalization continues to undermine the policy space of individual countries' economic decision-making, it is at the regional level that countries are able to retain some of their policy autonomy. In his view, international financial institutions like the IMF might face diseconomies of scale in the provision of financial services, for example crisis prevention and resolution. In contrast, regional and subregional financial institutions, serving as subsidiaries to the IMF, would be better equipped to deal with localized problems. Finally, Ocampo suggests that increased competition in the provision of financial services would be beneficial for small- and medium-size countries, whose current power in dealing with international financial institutions is highly limited because of their size. Moreover, regional institutions enjoy an increased level of ownership by small member countries. This contrasts with the current financial structure under which the voice of small nations is mostly negligible.

In addition to the arguments above, Agosin (2000) makes a normative argument for the partial pooling of reserves in Latin America based on contagion. Within the context of third generation crises, he argues that by protecting a country from a crisis occurrence, regional monetary institutions produce valuable positive externalities to other countries in the region. Mistry (1999) proposes regional institutions as mezzanine bulwarks of crisis response between national and global response mechanisms, which are critical to reduce "...the short- and long-term neighborhood costs of crisis mismanagements by international financial institutions throughout the developing world." He argues that regional crisis containment mechanisms are well-suited to restrain the spread of contagion through coordinated prevention and response. Mistry purports that the ability to respond in a unified manner creates a credible front of defense against speculation, limits the extent of trade and financial market disruptions, and avoids competitive devaluations among neighboring countries.

Latin American countries have embraced the precautionary role of reserves and have accumulated significant resources to deal with the vagaries of the international financial 
markets. Thus, while relying on the normative arguments presented above, this paper aims to empirically account for the role that the perception of contagion risk might have on a country's individual decision to accumulate reserves. By doing so, it assesses the potential benefits of creating regional reserve pools and similar mechanisms of crisis prevention and response. Moreover, it explores how reserve pooling, by internalizing the risk of contagion into the individual demand for reserves, might increase the level of insurance coverage, and consequently decrease the opportunity cost of precautionary accumulation.

\section{Methodology}

This paper tests the effects of perceived contagion risk on the demand for international reserves. The analysis is divided into two parts. First, it empirically extends the traditional Buffer Stock Model developed by Frenkel and Jovanovic (1981) by introducing a proxy for perceived contagion risk. Next, it carries out the results from this extension to illustrate the potential efficiency gains from hypothetical reductions in variability associated with regional reserve pooling. Data for some of the variables of interest, in particular the spread of the Emerging Bond Market Index, are not widely available pre-1999. This limits the number of quarterly observations available per country to sixty, and precludes the inclusion of important crisis episodes that affected the region during the 1990s (e.g., the 1994 1995 Mexican crisis). To partially overcome these limitations and to gain richness in the analysis, regressions in this paper are conducted using pooled series for the seven largest economies in the region. Unless otherwise stated, the data employed in this paper ranges from 1999Q1 2013Q4, and thus coincides with the period that follows the Asian Financial Crisis and the subsequent crises that took place throughout Latin America. Appendix 1 presents the descriptive statistics for the variables used in this analysis.

\section{A. Proxy for contagion risk}

The goal of this paper is not to quantify the probability that contagion will affect a 
particular country. Rather, the analysis presented here aims to account for the effect that instability in neighboring countries may have on a country's own optimal demand for reserves in the context of contagion. In a world of open economies, the precautionary role of reserves cannot stop at the borders of the country in question. In plain terms, getting fire insurance against your house is no longer sufficient if your neighbor's house now directly abuts yours. Thus, we develop here a proxy for this perception of contagion risk by measuring exchange market pressure among the neighbors of a given case country. This approximates the instability and potential for crises among neighbors.

Eichengreen, Rose, and Wyplosz (1996) provide a measure of Exchange Market Pressure (EMP), which they utilize to measure crisis episodes. ${ }^{7}$ The values of this exchange rate market pressure index allow for the quantification of potential crisis tendencies in neighboring countries, even if only within the context of currency crises. As argued by Eichengreen et al., not all potential currency crises materialize because in some instances central banks are able to deter them by running down their stocks of reserves, devaluing the currency, and/or increasing the interest rate. Moreover, if as previously suggested in the literature, Latin American crises tend to be contagious in nature, high positive EMP values in neighboring countries suggest that a crisis has or is likely to happen in the region. Therefore, high EMP values in the rest of the region can arguably be used to proxy perceived contagion risk, and thus should be expected to be associated with larger current levels of reserves.

However, rather than using direct levels of the EMP index, the variable PERCTG used in this empirical estimation consists of the aggregate of the number of standard deviations from their individual mean for each of the countries in the sample other than country $i$. That is,

$$
\operatorname{PERCTG}_{i, t}=\sum_{j \neq i} \frac{E M P_{j, t}-\overline{E M P}_{j}}{\sigma_{j}}
$$

where $E M P_{j, t}$ is the EMP value for country $j$ at time $t$, while $\overline{E M P}_{j}$ and $\sigma_{j}$ are,

They propose a weighted exchange market pressure index (EMP), such that:

$$
E M P_{i, t}=\left[\left(\alpha \% \Delta e_{i, t}\right)+\left(\beta \Delta\left(i_{i, t}-i_{G, t}\right)\right)-\left(\lambda\left(\% \Delta r_{i, t}-\% \Delta r_{G, t}\right)\right)\right]
$$

where $\mathrm{e}_{\mathrm{i}, \mathrm{t}}$ is the price of a unit of the center country currency in terms of country $i$ 's currency, $i_{G, t}$ is the short-term interest rate of the center country, and $r_{G, t}$ is the reserve ratio (reserves/M1) of the center country. Coefficients $\alpha, \beta, \lambda$ are weights. Moreover, in order to normalize the variances of the three factors, the weights $\alpha, \beta, \lambda$ are set such that:

$$
\alpha=1, \beta=\sigma\left[\Delta\left(i_{i, t}-i_{G, t}\right)\right] / \sigma\left[\left(\% \Delta e_{i, t}\right)\right], \lambda=\sigma\left[\left(\% \Delta r_{i, t}-\% \Delta r_{G, t}\right)\right] / \sigma\left[\left(\% \Delta e_{i, t}\right)\right]
$$

${ }^{8}$ The use of standard deviations is preferred to actual EMP values because the former allows us to retain the relative degree of pressure faced by individual countries, which otherwise is lost when aggregating across countries. 
respectively, the mean and standard deviation of the EMP series for country $j$ during the sample period.

Therefore, this measure of perceived contagion risk is equivalent to the aggregate of the $z$-scores for the EMP values of neighboring countries included in the sample. It captures the level of distress faced by a country's neighbors. A large number of the aggregate of standard deviations suggests large pressure on the exchange rate of neighboring countries, and can thus signal deteriorating conditions in the region, which arguably raise the potential for crisis at home. Consequently, under a precautionary approach to reserve accumulation, a high value of PERCTG is expected to be positively associated with the growth level of reserves demanded. Again, it is important to note that while the PERCTG index - as a measure of neighborhood distress - serves as a proxy for perceived contagion risk; it does not attempt to capture the direct effects of contagion on reserves once it has occurred.

\section{B. Buffer Stock Model}

The increasing interconnectedness in terms of trade and financial flows that has prevailed in the past few decades necessitates a reformulation of the traditional models of international reserve demand. The Buffer Stock model by Frenkel and Jovanovic (1981) provides a realistic theoretical framework for the accumulation of reserves from a precautionary approach. ${ }^{9}$ However, it fails to fully capture the potential risks that may originate from outside the country being studied. Contagion, as recent crises from Asia, Latin America, and Europe have shown, can wreak havoc on the economies of neighboring countries, which in some instances turn out to be innocent bystanders. Given the large potential adjustment costs that are associated with the spread of a

\footnotetext{
${ }^{9}$ In the Buffer Stock Model, changes in reserve holdings $d R(t)$ follow a Wiener process (driven by the stochastic process that governs payments and receipts). Monetary authorities face a cost minimization problem, where cost consists of the expected adjustment cost associated with the occurrence of a crisis event and the opportunity cost of holding reserves. Therefore, monetary authorities select their initial level of reserves $\left(R_{0}\right)$ in order to minimize this expected aggregate cost. Adjustments are necessary when the level of reserves reaches a lower bound, which for the sake of simplicity is assumed to be zero. Solving for the optimal stock of reserves yields, Frenkel and Jovanovic (1981) derive the following equation:$$
\ln R=b_{0}+b_{1} \ln \sigma+b_{2} \ln r+u,
$$

where $\sigma$ is a volatility measure of reserves, $r$ accounts for the opportunity cost of holding reserves, and $u$ is the error term. Moreover, and in line with the earlier theoretical work in Triffin (1961) and Olivera (1969) - both of which had proposed the level of trade (represented by imports) as a determinant of reserve demand-Frenkel and Jovanovic (1981) further extended their structural specification to: $\ln R=b_{0}+b_{1} \ln \sigma+b_{2} \ln r+b_{3} \ln M+u$,

where $\mathrm{M}$ accounts for the level of imports. The level of reserves demanded is expected to be positively correlated with imports, through a precautionary channel in which countries with larger imports face higher potential adjustment costs.
} 
crisis, it seems theoretically necessary to incorporate this risk factor into the traditional specification of the Buffer Stock Model in order to avoid omitted variable bias. Thus, the basic structural extension proposed in this paper is such that:

$$
\begin{aligned}
\ln \left(\text { Reserves }_{i, t}\right) & =\beta_{0}+\beta_{1} \ln \left(\text { RESVAR }_{i, t}\right)+\beta_{2} \ln \left(\text { EMBI }_{i, t}\right) \\
& +\beta_{3} \ln \left(\operatorname{VULNERABILITY~}_{i, t}\right)+\beta_{4} \text { PERCTG }_{i, t}+\mu_{t}
\end{aligned}
$$

All variables (with the exception of PERCTG and PORTFOLIO) in this empirical specification are expressed in logarithmic terms. The variable PERCTG is kept in levels in order to retain its economic meaning. The dependent variable lnReserves accounts for the natural log of the stock of total reserves, excluding gold, for each country under consideration. Data for this variable are measured in millions of currents of US dollars and is obtained from the IMF's International Financial Statistics database. In line with the original specification in Frenkel and Jovanovic (1981), the first regressor, $\ln (R E S V A R)$, serves as a proxy of idiosyncratic country risk by tracking the natural log of the variance of reserves. This variance is calculated based on an eight-quarter moving window of the de-trended level of total reserves, which in turn is obtained using a Hodrick-Prescott filter. Higher variance in the level of reserves in previous periods is assumed to implicitly capture the risk associated with the economy being insured, and thus it is expected to be positively correlated with the current level of demand for reserves.

Unlike Frenkel and Jovanovic (1981), who use government bond yields as a proxy for the opportunity cost of holding reserves, the specification used here relies on the Emerging Bond Market Index Plus (EMBI) spread to account for this cost. The natural $\log$ of the EMBI spread, measured in basis points, captures the gap between the total returns on sovereign debt instruments, e.g., Brady bonds, euro bonds, from emerging countries and the total rate of return on risk-free US Treasury bills of comparable maturity terms. Countries with a high $\ln (E M B I)$ spread face a relatively higher cost of finance in international markets. ${ }^{10}$ Therefore, it is expected that higher opportunity costs are negatively associated with the level of reserves demanded. EMBI Spread data were obtained using the EMBI+ index developed by JPMorgan and by calculating quarterly averages.

Frenkel and Jovanovic (1981) used the level of imports as a measure of the size

\footnotetext{
${ }^{10}$ As with most emerging countries, Latin American nations tend to have low private and public savings rates, which coupled with a restricted tax base tends to make their governments net international debtors. The difference between what emerging markets have to pay in order to borrow abroad (i.e., the return on sovereign bonds) and the return that they get on their savings (i.e., especially the yield on US treasury securities) is particularly relevant for countries which are indirectly financing their reserve holdings by issuing a debt of their own.
} 
of the asset to be covered. That is, in the event of a crisis, the value of imports is used as a measure of the level of coverage that reserves should provide. However, the liberalization of the capital accounts of developing countries including those in Latin America makes this measure obsolete. As argued in Titelman et al. (2008), unlike the crises of the 1970s and 1980s, recent crises in Latin America tend to be financial in nature. With increased exposure to foreign financial flows, the reversal of net capital inflows has a large potential to wreak havoc on the domestic economy. Thus, a measure of the asset to be covered by reserves should also consider net portfolio flows for the country of interest. The variable $\ln$ (VULNERABILITY) in this context is analogous to the scalar variable $\ln (M)$ introduced in the original Buffer Stock Model specification. In addition to the level of quarterly imports, the variable $\ln$ (VULNERABILITY) accounts for net portfolio investment. Data on net portfolio capital inflows and imports are available from IMF's IFS database and is measured in millions of current US dollars. Given the insurance perspective of the Buffer Stock Model, it is expected that the larger the natural log of aggregate of imports and net portfolio capital flows, the larger the amount of reserves demanded by the holding country. As a sensitivity test, models $1 \mathrm{~B}$ and $1 \mathrm{C}$, presented in Table 3, disaggregate this scalar variable into its two components. ${ }^{11}$

An alternative measure for asset coverage from reserve accumulation is a country's short-term debt obligations. Several authors including Bussière and Mulder (1999) have previously found short-term debt to be a positive and significant predictor of the level of reserves demanded. In order to test this alternative specification, Models 2 and $2 \mathrm{~A}$ in Table 3 include the variable $\ln (S T D E B T)$. Short-term debt is defined as the total (public and private) debt obligations with an original maturity of one year or less. Data for this variable was obtained from the Special Data Dissemination Standard (SDDS) component of the Quarterly External Debt (QEDS) dataset compiled by the IMF and the World Bank. Data limitations for this variable preclude the inclusion of Venezuela in the estimations of the second set of specifications.

A Fisher test, as developed in Maddala and $\mathrm{Wu}$ (1999), shows that with the exception of PERCTG and PORTFOLIO, all of the variables considered have unit roots when measured in levels and are stationary of degree 1 (see Appendix 2). Based on these findings, first-difference least square estimations with time fixed effects are conducted based on the extended models outlined above. The time fixed effects specification is included to account for those shocks which are common to all countries, but which

\footnotetext{
${ }^{11}$ The variable PORTFOLIO is expressed at levels to retain economic significance.
} 
change across time. Moreover, by running the model in differences, the country fixed effects are implicitly eliminated from the estimation, and thus are not included in this empirical exercise.

\section{Contagion risk and the benefits of reserve pooling}

The estimated coefficients for the variable PERCTG from the model specifications outlined above provide a parameter for the partial effect that contagion risk has on the growth rate of reserves demanded. It is possible to build upon this finding to establish a basic estimate of the amount of reserves that countries have been accumulating as part of their protection mechanism against perceived contagion risk. This theoretical exercise, presented in the following section, aims to capture the cost of the precautionary accumulation of reserves associated with perceived contagion risk as defined in this paper.

To take the analysis one step further, while connecting it to the literature on regional integration, we estimate the hypothetical gains from reserve pooling in Latin America. A traditional method of assessing the benefits of reserve pooling in the literature has been through the calculations of coverage ratios (Dodsworth 1992, Eichengreen 2007, Rajan et al. 2003) based on the Theory of Clubs as developed by Buchanan (1965). ${ }^{12}$ A replication of this simplified method for a pool made up of the seven largest countries in Latin America is presented in the following section.

As argued by others in the literature (Ocampo 2006, Mistry 1999), mechanisms of reserve pooling are likely to reduce the risk of contagion occurring at the regional level by providing enhanced liquidity and coordinated responses and monitoring. Reduced contagion risk, along with an expanded toolbox of crisis response, is likely to lower variability in the balance of payments of member countries. Unfortunately, at present

\footnotetext{
${ }^{12}$ Under autarky, each country faces a given coverage ratio, $C_{i}$, based on its level of liquidity and the variation of its balance of payments, such that:

$$
G_{A i}=\frac{R_{i}}{\operatorname{Var} R_{i}}
$$

where $R_{i}$ is the average level of reserves of country $i$, and $\operatorname{Var} R_{i}$ is the variation of reserves expressed as the standard deviation for a given period (Q1-1999 to Q1-2009 in this case). Under a pooling arrangement, the coverage ratio, $C_{p i}$, can be expressed as

$$
G_{P i}=\frac{R_{i}+\sum_{k \neq i} R_{k} \rho}{\operatorname{Var}\left[R_{i}+\sum_{k \neq i} R_{k} \rho\right]}
$$

The term $\rho$ accounts for degree of reserve pooling $(0 \leq \rho \leq 1)$. Reserve pooling mechanisms are beneficial to a country as long as the coverage ratio it faces as a result of pooling is lower than that faced under autarky $\left(C_{p i}>C_{A i}\right)$.
} 
there are limited formal empirical estimations of the true relationship between the level of reserve pooling and the variability of reserves. Thus, an extended cost-benefit analysis of the decision to join a pool by individual countries is necessary and should be addressed in future research. In the meantime, it is useful to build upon the coverage ratio method described above by accounting for hypothetical reductions in variability that might result from decreases in the perceived contagion risk in the region. Coverage ratios under alternative scenarios of variability reduction are calculated for each country as follows:

$$
G_{P *_{i}}=\frac{R_{i}+\sum_{k \neq i} R_{k} \rho}{\left[\operatorname{Var}\left(R_{i}+\sum_{k \neq i} R_{k} \rho\right)\right](1-\tau \rho)}
$$

where $\tau$ accounts for different multiples of hypothetical percentage reductions in the variability of the denominator, such that $0 \leq \tau \leq 0.1$. In lieu of a formal relationship, this hypothetical framework, based on a simplified linear relationship, allows for the illustration of potential improvements in coverage ratios that would emerge from reserve pooling $\left(C_{p^{*} i} \geq C_{p i}\right)$. The next section of this paper presents simulations based on different hypothetical levels of reduced variability and reserve pooling, as well as the potential increases in insurance coverage associated with these scenarios.

\section{Findings}

\section{A. Results}

Table 3 presents the empirical results for six different specifications based on the unbalanced quarterly panel for the seven countries under consideration during the Q11999 to Q4-2013 period. Model 1 is based on the basic specification of the Buffer Stock Model, excluding PERCTG. Model 1A introduces contagion risk into Model 1. Model $1 \mathrm{~B}$ and $1 \mathrm{C}$ disaggregate VULNERABILITY into its two components to test for the sensitivity of the results. Models 2 and 2A repeat the exercise above, but with $\ln (S T D E B T)$ as an alternative specification to the $\ln ($ VULNERABILITY) variable. Pedroni tests for cointegration reveal that the variables in the models are not cointegrated, and 
thus all of the variables included (with the exception of PERCTG and PORTFOLIO) are run in first differences to correct issues of non-stationarity in the original series (see Appendix 2).

Table 3. Panel regression result

Dependent: $\ln ($ reserves $)$

(least squares with time fixed effect)

\begin{tabular}{|c|c|c|c|c|c|c|}
\hline Model & 1 & 1a & $1 b$ & 1c & 2 & $2 a$ \\
\hline$C$ & $\begin{array}{c}0.019 * * \\
(0.005)\end{array}$ & $\begin{array}{l}0.02 * * \\
(0.005)\end{array}$ & $\begin{array}{c}0.009 * * \\
(0.005)\end{array}$ & $\begin{array}{l}0.011 * * \\
(0.005)\end{array}$ & $\begin{array}{c}0.029 * * \\
(0.004)\end{array}$ & $\begin{array}{l}0.027 * * \\
(0.004)\end{array}$ \\
\hline Dln(resvar) & $\begin{array}{l}-0.001 \\
(0.011)\end{array}$ & $\begin{array}{c}0.002 \\
(0.011)\end{array}$ & $\begin{array}{l}-0.003 \\
(0.011)\end{array}$ & $\begin{array}{l}0.0001 \\
(0.011)\end{array}$ & $\begin{array}{l}-0.009 \\
(0.010)\end{array}$ & $\begin{array}{l}-0.008 \\
(0.010)\end{array}$ \\
\hline$D \ln (e m b i)$ & $\begin{array}{c}-0.063 * * \\
(0.032)\end{array}$ & $\begin{array}{c}-0.061 * \\
(0.031)\end{array}$ & $\begin{array}{c}-0.079 * * \\
(0.031)\end{array}$ & $\begin{array}{c}-0.077^{* *} \\
(0.031)\end{array}$ & $\begin{array}{c}-0.066^{* *} \\
(0.024)\end{array}$ & $\begin{array}{c}-0.065^{* *} \\
(0.024)\end{array}$ \\
\hline Dln(vulnerability) & $\begin{array}{l}0.07 * * \\
(0.018)\end{array}$ & $\begin{array}{c}0.069 * * \\
(0.017)\end{array}$ & & & & \\
\hline Dln(imports) & & & $\begin{array}{c}0.145^{* *} \\
(0.061)\end{array}$ & $\begin{array}{c}0.126 * * \\
(0.061)\end{array}$ & & \\
\hline Portfolio & & & $\begin{array}{l}0.0000046^{* *} \\
(0.00000138)\end{array}$ & $\begin{array}{l}0.0000037 * * \\
(0.00000141)\end{array}$ & & \\
\hline$D \ln (s t d e b t)$ & & & & & $\begin{array}{c}0.122 * * \\
(0.031)\end{array}$ & $\begin{array}{l}0.112 * * \\
(0.031)\end{array}$ \\
\hline Perctg & & $\begin{array}{c}0.016 * * \\
(0.006)\end{array}$ & & $\begin{array}{c}0.014 * * \\
(0.006) \\
\end{array}$ & & $0.01^{*}$ \\
\hline$R^{2}$ & 0.247 & 0.264 & 0.249 & 0.261 & 0.37 & 0.379 \\
\hline Cross-Sections & 7 & 7 & 7 & 7 & 6 & 6 \\
\hline Periods & 59 & 59 & 59 & 59 & 47 & 47 \\
\hline Observations & 401 & 401 & 405 & 405 & 256 & 256 \\
\hline
\end{tabular}

(Notes) ** Statistically significant at the 5\% level * Statistically significant at the $10 \%$ level. Standard Errors reported in parentheses.

The results on this table provide empirical support for the hypothesis that perceived contagion risk is positively and significantly correlated with the optimal level of reserves that a country demands. Across the six different model specifications presented, the coefficient for PERCTG remains positive, significant, and of a mostly consistent magnitude. According to these results, an increase by one unit in the PERCTG variable 
is associated with about a 0.016 percentage point increase in the quarterly rate of growth of reserves demanded. Thus, an increase in perceived contagion risk appears to trigger an acceleration in the accumulation of reserves. Moreover, the inclusion of PERCTG as a regressor improves the explanatory power of the model, as evidenced by the increase in the values of R-square from Models 1 and 2 to Models $1 \mathrm{~A}$ and 2A, respectively.

An interesting result from these empirical estimations is the lack of statistical significance (and in some cases negative sign) of the coefficient for the estimator $d \ln (R E S V A R)$, which stands in direct contradiction to the expectations and the traditional findings in the literature, including those in Frenkel and Jovanovic (1981). However, once one takes into consideration that the first-differenced natural log of the variance of detrended reserves from previous periods is used as a proxy for the idiosyncratic country risk to correlate today's level of demand for reserves, this finding is not as surprising. In addition to capturing idiosyncratic risk, the growth rate of variation in previous levels of detrended reserves might also capture previous periods' response in the growth rate of reserves to ongoing shocks. Future specifications of this model should revisit the appropriateness of the use of variance of de-trended reserves as a proxy for idiosyncratic risk by either extending the period of the moving window or by finding another measure altogether.

As shown in Table 3, the remaining coefficients are in accordance with expectations in terms of their signs. Moreover, all of them (again with the exception of the coefficient of $d \ln (R E S V A R)$ are statistically significant at the $10 \%$ level. According to these results, all else equal, a one percentage point increase in the growth rate of the opportunity cost of reserves, as measured by the EMBI+ spread, is associated with approximately a 0.06 percentage point decrease in the quarterly growth level of reserves demanded. Similarly, a one percentage point increase in the growth rate of the aggregate of imports and net portfolio investment inflows (vulnerability) tends to be matched by a 0.07 percentage point rise in the rate of growth of demanded reserves. Moreover, the alternative specification $d \ln (S T E B T)$ appears to provide higher explanatory power to the model than $d \ln (V U L N E R A B I L I T Y)$. According to the results of Model 2A, a one percentage point increase in the growth rate of a country's short-term debt is associated with a 0.11 percentage point increase in the quarterly growth rate of reserves demanded. Overall, Models $1 \mathrm{~A}$ and 2A, i.e., those including perceived contagion risk, explain $26.4 \%$ and $37.9 \%$ of the variation in the growth rate of reserves. 


\section{B. Effects of contagion risk}

The main finding from the previous section is significant in itself. However, it is important to conceptualize the effects of perceived contagion risk on reserve demands in order to assess the economic meaning of this effect, especially as it relates to the real cost of holding these additional reserves. A simple way of making this assessment is by forecasting the annual change in the level of reserves due to hypothetical changes in perceived contagion risk. In other words, if one assumes that the prevailing average growth rate of reserves (from the observable sample) would continue into the future, ceteris paribus, it is expected that the level of reserves would grow accordingly. However, on the contrary, if one assumes a change in the level of perceived contagion risk in the last period by one unit, it will be associated with a $0.016 \%$ increase in the growth rate of reserves - and thus in the level of reserves that would be accumulated. The gap between these two growth paths approximates the cost of perceived contagion risk as presented here. The hypothetical annual cost of changes in perceived contagion risk in relation to GDP can thus be expressed as:

$$
\text { Annual cost of perceived contagion risk }=\frac{\sum_{t=1}^{4}\left[R_{i, 0}\left(\dot{R}_{i,}+0.02 \Delta C_{i, 1}\right)-R_{i, 0}\left(\dot{R}_{i}\right)\right]}{\sum_{t=1}^{4} G D P_{i, t}}
$$

Here, $R_{i, 0}$ corresponds to country $i$ 's level of reserves at the last observed period, $\dot{R}_{i}$ is the average quarterly growth rate of reserves for country $i$, and $\Delta C_{i, 1}$ is the hypothetical change in level of perceived contagion risk faced by country $i$ at the first forecast period.

Figure 2 captures this cost under different scenarios involving hypothetical changes in contagion risk. As shown in this figure, the costs of accumulating additional reserves as a result of changes in contagion risk are not negligible. For instance, in the case of Peru an increase in the level of perceived contagion risk by two units would be associated with a change in reserves equivalent to about $0.11 \%$ of this country's annual GDP. While this figure might not seem like a significant amount, it is important to put it in perspective in relation to the country's spending on social priorities. For instance, in 2012 Peru spent only just above $1 \%$ of its GDP on primary education (World Bank 2014). Therefore, even a tenth of $1 \%$ of GDP could arguably be redirected toward more productive ends. As argued in the following section, mechanisms like regional reserve pooling - aimed at reducing perceived contagion risk - might free up significant resources, which could in turn be redirected to alternative development purposes. 
Figure 2. Change in reserves due to changes in perceived contagion

(as \% of Annual GDP)

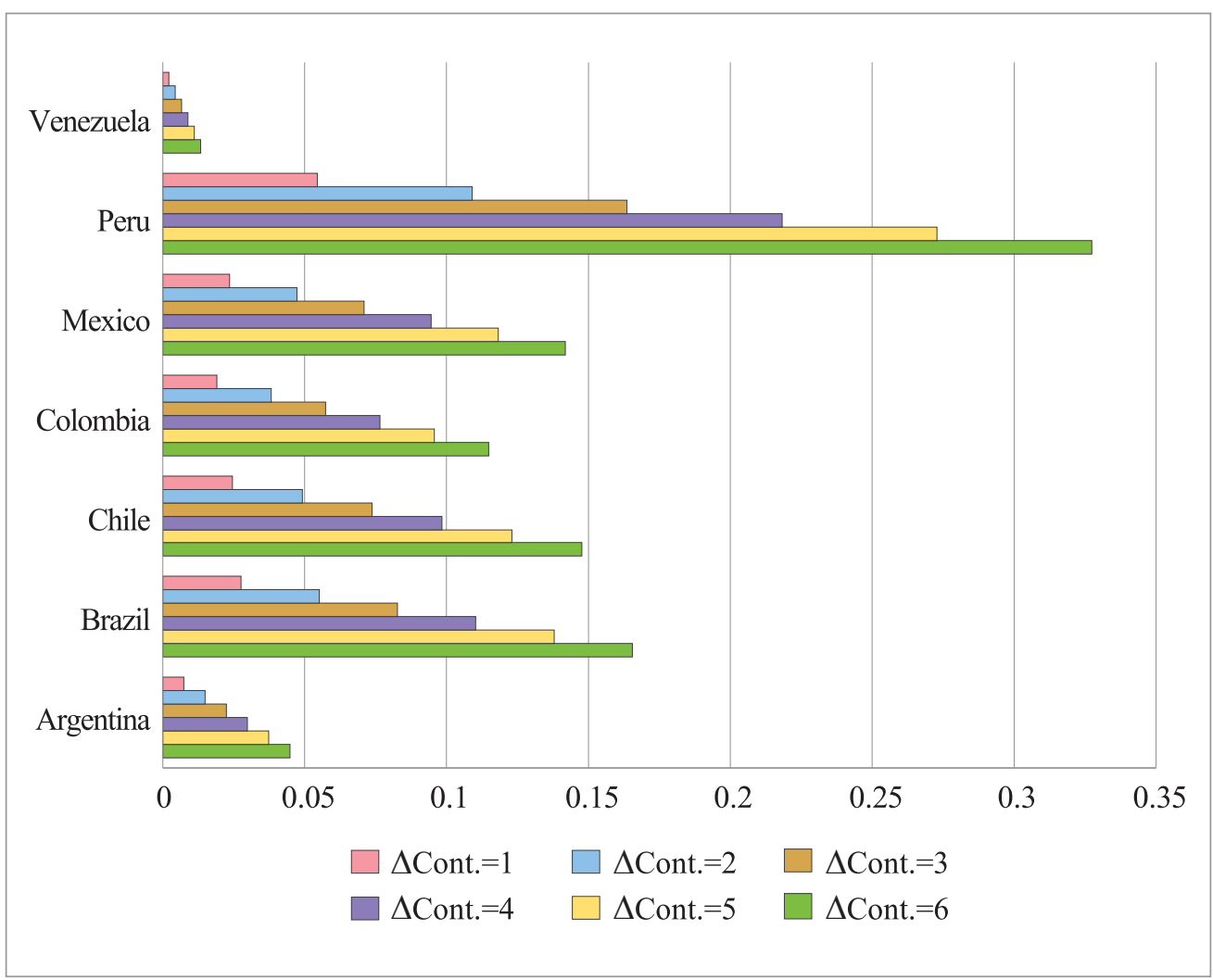

\section{Potential benefits of pooling scenarios}

Table 4 presents the coverage ratio under different degrees of reserve pooling for the countries under consideration during the sample period. In line with the findings in Eichengreen (2007), this paper finds that under this traditional method of calculating coverage ratios some low variability countries would see their coverage reduced as a result of pooling with high variability countries. Based on this result, countries like Argentina and Chile would be most negatively affected by reserve pooling, and would thus have little incentive to join such arrangements. 
Table 4. Coverage ratios under reserve pooling

(1999 2013)

\begin{tabular}{|l|c|c|c|c|c|c|c|}
\hline & Argentina & Brazil & Chile & Colombia & Mexico & Peru & Venezuela \\
\hline $\mathbf{r}=\mathbf{0}$ & 2.34 & 1.19 & 2.32 & 1.90 & 2.00 & 1.34 & 2.25 \\
\hline $\mathbf{r}=\mathbf{0 . 1}$ & 1.98 & 1.26 & 1.84 & 1.71 & 1.88 & 1.50 & 2.29 \\
\hline $\mathbf{r}=\mathbf{0 . 2}$ & 1.83 & 1.32 & 1.74 & 1.67 & 1.80 & 1.55 & 1.94 \\
\hline $\mathbf{r}=\mathbf{0 . 3}$ & 1.76 & 1.37 & 1.70 & 1.65 & 1.75 & 1.58 & 1.81 \\
\hline $\mathbf{r}=\mathbf{0 . 4}$ & 1.71 & 1.42 & 1.67 & 1.64 & 1.72 & 1.59 & 1.74 \\
\hline $\mathbf{r}=\mathbf{0 . 5}$ & 1.69 & 1.46 & 1.66 & 1.64 & 1.69 & 1.60 & 1.70 \\
\hline $\mathbf{r}=\mathbf{0 . 6}$ & 1.67 & 1.50 & 1.65 & 1.63 & 1.67 & 1.61 & 1.68 \\
\hline $\mathbf{r}=\mathbf{0 . 7}$ & 1.65 & 1.54 & 1.64 & 1.63 & 1.66 & 1.61 & 1.66 \\
\hline $\mathbf{r}=\mathbf{0 . 8}$ & 1.64 & 1.57 & 1.63 & 1.63 & 1.64 & 1.62 & 1.64 \\
\hline $\mathbf{r}=\mathbf{0 . 9}$ & 1.63 & 1.60 & 1.63 & 1.62 & 1.63 & 1.62 & 1.63 \\
\hline $\mathbf{r}=\mathbf{1}$ & 1.62 & 1.62 & 1.62 & 1.62 & 1.62 & 1.62 & 1.62 \\
\hline
\end{tabular}

However, as previously argued in this paper and by others in the literature, reserve pooling through the expansion of crisis response, resources and coordination is likely to reduce contagion risk as expressed in the lower balance of payment variability of member countries. Moreover, given the empirical findings presented in Table 3, these potential decreases in the level of contagion risk would have tangible consequences for the opportunity cost of precautionary reserve accumulation. In that vein, the table in Appendix 3 illustrates the potential gains in coverage ratios once one accounts for reductions in variability $(\tau)$. Shaded cells capture those situations under which the coverage ratio is improved relative to the non-pooling baseline. From this table, it can be seen that once contagion risk (and thus variability) reductions are considered, the prospects for reserve pooling in Latin America change considerably.

Given a sufficiently high reduction in variability, there could be significant incentives for all countries in the region to join a regional reserve pool. However, we can also see from these figures that relatively low-variability countries like Argentina, Chile, and Mexico would require a combination of significant reductions in variability along with a large degree of pooling for such an arrangement to make sense for them. On the other hand, a country like Colombia, which under the traditional method would not benefit 
from pooling, would see its coverage ratio improve even from a small reduction in variability and pooling. For example, 30\% hypothetical reduction in variability with a $50 \%$ level of reserve pooling.

\section{Conclusion}

The last two decades have been characterized by two key trends in international finance, particularly as it relates to developing countries. First, these countries have accumulated unprecedented levels of international reserves for countercyclical purposes. Second, institutions of regional cooperation and integration, such as regional reserves pools, have emerged and strengthened. In the Latin American context, both of these trends have been visibly present. These nations continue to demand high levels of reserves to match the increasing openness of their current and financial accounts, as well as the increased volatility that comes with it. While relatively high levels of foreign reserves allow for deterrence and more manageable adjustments in the face of financial crisis episodes, they come at a significant opportunity cost.

Traditional optimal reserve models, such as the Buffer Stock Model, have incorporated this cost, as well as the potential re-adjustment cost to develop a costminimization framework that captures the optimal level of insurance that countries should purchase. Nevertheless, the continued trend towards globalization and particularly capital account liberalization on the part of emerging economies necessitates a reconsideration of the traditional models by incorporating risks exogenous to the country in question. This paper explores how perceived contagion risk, in particular, might be a part of this insurance acquisition decision by Latin American countries; that is, the intent is not to overstate the importance of perceived contagion risk in the process of accumulating reserves, but rather to test the degree to which it might be a factor. While limited to the post-1999 period, the empirical findings presented here suggest that in an increasingly world of open-economy with imperfect information, these countries are concerned with the conditions both within their borders, but also with those of surrounding nations which might have significant effects on their own crisis prospects due to contagion risk. Based on a proxy for perceived contagion risk, this paper finds that an increase by one unit in the PERCTG variable (i.e. one additional standard deviation in 
the aggregate EMP index for neighboring countries) is associated with approximately a $0.016 \%$ age point increase in the quarterly growth rate of reserves demanded. Moreover, by taking this result a step further, it shows that the estimated cost of holding reserves due to contagion risk is not negligible, especially when taking into consideration the otherwise capital-deprived nations that hold them. With this background, it seems clear that any mechanism that could reduce contagion risk in the region would also free up significant resources that could be redirected to more productive ends.

Many in the literature have provided normative arguments in favor of regional cooperation mechanisms in the region. By empirically showing that Latin American countries insure against perceived contagion risk, this paper provides an additional impetus for the creation of such mechanisms. Regional reserve pools, as complements to the traditional international financial institutions, are uniquely positioned to prevent and respond to regional financial crises in a timely manner, and thus reduce the threat of contagion. By building on this assumption, this paper showed that unlike previous analyses which ignore the potential reduction in contagion risk from pooling, a regional reserve pool in Latin America might prove beneficial to most countries in the region even under relatively small reductions in balance of payment variability.

These findings may inform the promotion of countercyclical regional arrangements aimed at lowering cost, while providing comparable levels of insurance. If Latin American countries insure not only against their own risk, but also the risk originating from deteriorating conditions in the neighborhood, co-insurance mechanisms like regional reserve pool funds (e.g., the Latin American Reserve Fund) and swap arrangements might prove useful in taking advantage of the potential cost-savings afforded by these schemes. In other words, these findings imply that countries have a stake at ensuring that a crisis does not occur in a neighboring country, which consequently would decrease their own exposure to contagion risk, and thus their need for reserve holdings.

Received 1 September 2014, Revised 19 January 2015, Accepted 24 July 2015 


\section{References}

Agosin, Manuel. "Fortaleciendo la institucionalidad financiera en Latinoamérica." Serie Temas de Coyuntura, ECLAC, No. 9 (2000).

Aizenman, Joshua, and Jaewoo Lee. "International Reserves: Precautionary Versus Mercantilist Views, Theory and Evidence." Open Economies Review 18, No. 2 (2007): 191-214.

Aizenman, Joshua, and Jaewoo Lee. "Financial versus Monetary Mercantilism." The World Economy 31, No. 5 (2008): 593-611.

Bahmani-Oskooee, Mohsen, and Ford Brown. "Demand for International Reserves: A Review Article." Applied Economics 34, No. 10 (2002): 1209-1226.

Basnet, Hem, and Subhash Sharma. "Economic Integration in Latin America." Journal of Economic Integration 28, No. 4 (2013): 551-579.

Buchanan, James M. “An Economic Theory of Clubs.” Economica 32, No. 125 (1965): $1-14$.

Burki, Shahid J., and Sebastian Edwards. Latin America after Mexico: quickening the pace. Washington, D.C.: World Bank, 1996.

Bussière, Matthieu, and Christian Mulder. "External Vulnerability in Emerging Market Economies: How High Liquidity can Offset Weak Fundamentals and the Effects of Contagion." IMF Working Paper, No. 99/88 (1999).

Calvo, Sara, and Carmen Reinhart. "Capital Flows to Latin America: Is There Evidence of Contagion Effects?' World Bank’s Policy Research Working Paper, No. 1619 (1996).

CEPALStat. United Nations Economic Commission for Latin America and the Caribbean. (2014).

Cheung Yin-Wong, and Rajeswari Sengupta. "Accumulation of reserves and keeping up with the Joneses: The case of LATAM economies." International Review of Economics \& Finance 20, No. 1 (2011): 19-31.

Cooper, Richard N. "The Relevance of International Liquidity to Developed Countries." American Economic Review 58, No. 2 (1968): 625-636.

Dodsworth, John R. "Reserve Pooling: An Application of the Theory of Clubs." 
Economia Internazionale 44 (1992): 209-222.

Dooley, Michael P., David Folkerts-Landau and Peter Garber. International Financial Stability. New York: Deutsche Bank, 2005.

Eichengreen, Barry, Andrew Rose, and Charles Wyplosz. "Contagious Currency Crises: First Tests.” Scandinavian Journal of Economics 98, No. 4 (1996): 463-484.

Eichengreen, Barry. "Insurance Underwriter or Financial Development Fund: What Role for Reserve Pooling in Latin America.” Open Economies Review 18, No. 1 (2007): 2752.

Forbes, Kristin and Roberto Rigobon. "Measuring Contagion: Conceptual and Empirical Issues.” In International Financial Contagion, edited by Stijn Claessens, and Kristin Forbes, 43-66. Norwell, MA: Springer, 2001.

Frenkel, Jacob and Boyan Jovanovic. "Optimal International Reserves: A Stochastic Framework.” The Economic Journal 91 (1981): 507-514.

Glick, Reuven, and Andrew Rose. "Contagion and Trade: Why are Currency Crises Regional?" Journal of International Money and Finance 18, No. 4 (1999): 603-617.

Greenspan, Alan. "Currency Reserves and Debt." Remarks at the World Bank Conference on Trends in Reserve Management, Washington, DC, April 29, 1999.

Heller, Robert H. “Optimal International Reserves.” The Economic Journal 76 (1966): 296-311.

International Monetary Fund, Issues in Reserves Adequacy and Management. Report prepared by the Monetary and Exchange Affairs Department and Policy Development and Review Department. Washington, DC: International Monetary Fund, 2001.

International Monetary Fund, International Financial Statistics (2014). Available from IMF Web site: https://www.imf.org/external/data.htm.

Kaminsky, Graciela and Carmen Reinhart. "The Twin Crises: The causes of Banking and Balance-of Payments Problems." The American Economic Review 89, No. 3 (1999): 473-500.

Machinea, José Luis, and Guillermo Rozenwurcel. "Macroeconomic Coordination in Latin America: Does it have a Future?" In Regional Financial Cooperation edited by José Antonio Ocampo, 164-199. Washington, D.C.: United Nations Economic 
Commission for Latin America and the Caribbean, Brookings Institution Press, 2006.

Maddala, G.S., and Shaowen Wu. "A Comparative Study of Unit Root Tests with Panel Data and a New Simple Test." Oxford Bulletin of Economics and Statistics 61, No. 1 (1999): 631-652.

Mistry, Percy S., "Coping with Financial Crises: Are Regional Arrangements the Missing Link?" in International Monetary and Financial Issues for the 1990s. Vol. 10, Geneva: United Nations Conference on trade and Development (UNCTAD), 1999.

Ocampo, José Antonio. "Recasting the International Financial Agenda." Center for Economic Policy Analysis Working Paper, No. 19 (2000).

Ocampo, José Antonio. "Regional Financial Cooperation: Experiences and Challenges." In Regional Financial Cooperation edited by José Antonio Ocampo, 1-39. Washington, D.C.: United Nations Economic Commission for Latin America and the Caribbean, Brookings Institution Press, 2006.

Olivera, Julio H.G. "A note on the optimal rate of growth of international reserves." Journal of Political Economy 77 (1969):2245-8.

Perez Caldentey, Esteban, “Los Motivos Mercantilista y Precaución.” Unpublished manuscript for ECLAC, Santiago, Chile, 2009.

Rajan, Ramkishen S., Reza Siregar, and Graham Bird. "Examining the Case for Reserve Pooling in East Asia: Empirical Analysis." Center for International Economic Studies Discussion Paper, No. 0323 (2003).

Rodrik, Dani. "The Social Cost of Foreign Exchange Reserves." International Economic Journal 20, No. 3 (2006): 253-66.

Rosero, Luis and Bilge Erten. "Delinking Through Integration: A Dependency Analysis of Regional Financial Integration.” Critical Sociology 36, No. 2 (2010): 221-242.

Strauss-Kahn, Dominique. "An IMF for the $21^{\text {st }}$ Century." Address delivered at the International Monetary Fund's Bretton Woods Committee Annual Meeting, Washington, D.C., February 26, 2010.

Stiglitz, Joseph. Globalization and its Discontents. New York: W.W. Norton \& Company, 2002.

Titelman, Daniel, Esteban Perez Caldentey, and Rodolfo Minzer. "Comparación de 
la Dinámica e Impactos de los Choques Financieros y de Términos del Intercambio en América Latina en el Período 1980-2006." Serie Financiamiento del Desarrollo, ECLAC, No. 203 (2008).

Triffin, Robert. Gold and the Dollar Crisis. New Haven, CT: Yale University Press, 1961.

World Bank, World Development Indicators (2014), Available at World Bank Web site: http://data.worldbank.org/data-catalog/world-development-indicators 


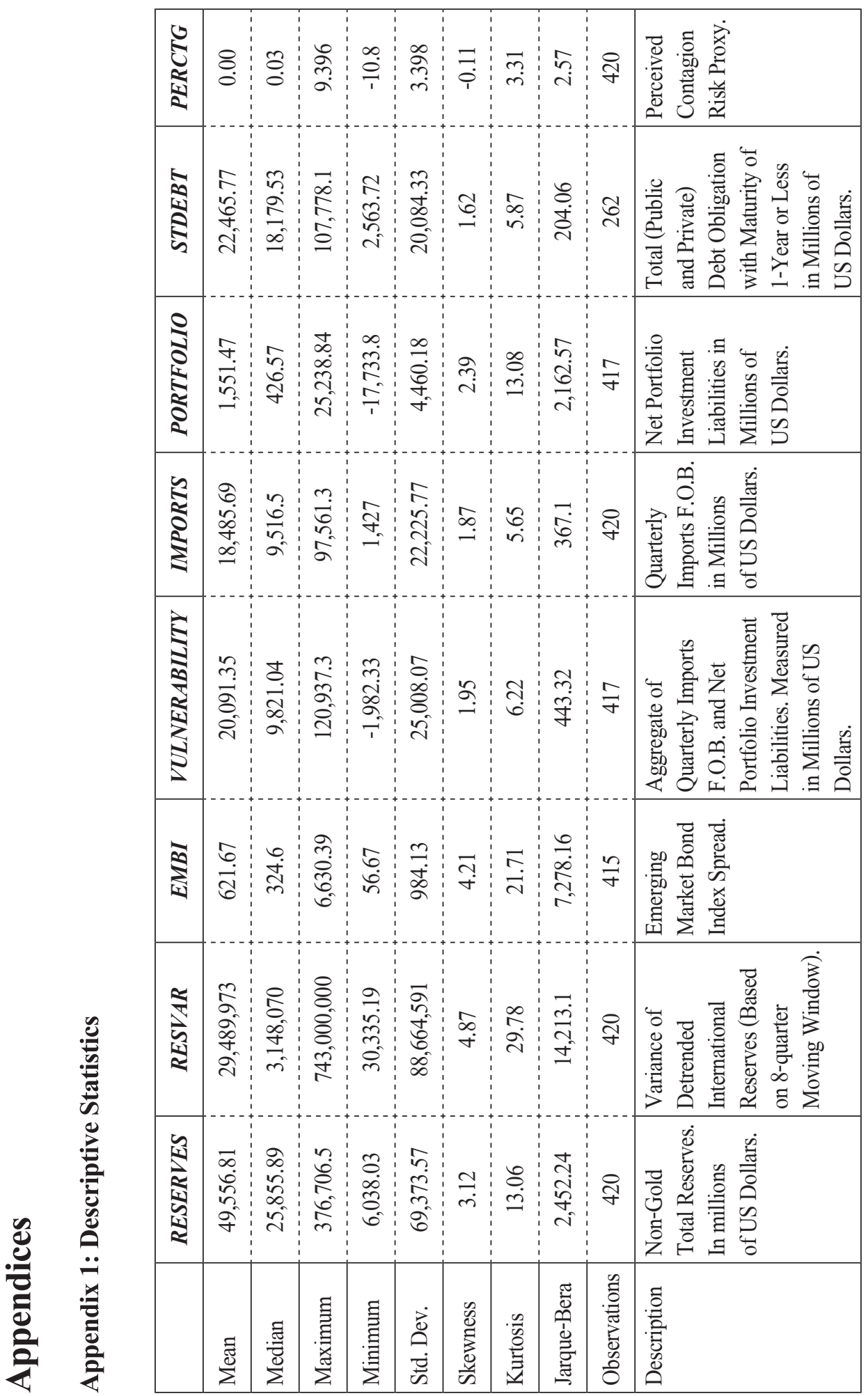




\section{Appendix 2: Panel Unit Root Test (Fisher)}

Ho: Unit Root

\begin{tabular}{|l|c|c|c|c|}
\hline Variable & \multicolumn{2}{|c|}{ At Levels } & \multicolumn{2}{c|}{ First-Difference } \\
\hline & Chi-square & $P$-value & Chi-square & $P$-value \\
\hline $\ln ($ RESERVES $)$ & 13.02 & 0.53 & 211.54 & 0 \\
\hline $\ln ($ RESVAR $)$ & 10.72 & 0.71 & 150.26 & 0 \\
\hline $\ln ($ EMBI $)$ & 15.56 & 0.34 & 189.63 & 0 \\
\hline $\ln ($ VULNERABILITY $)$ & 11.35 & 0.66 & 269.42 & 0 \\
\hline $\ln ($ IMPORTS $)$ & 16.59 & 0.28 & 199.79 & 0 \\
\hline PORTFOLIO & 122.72 & 0.00 & - & - \\
\hline $\ln ($ STDEBT $)$ & 9.62 & 0.65 & 131.31 & 0 \\
\hline PERCTG & 64.07 & 0.00 & - & - \\
\hline
\end{tabular}


Appendix 3: Coverage ratios under reserve pooling with hypothetical reductions in contagion risk

\begin{tabular}{|c|c|c|c|c|c|c|c|c|c|c|c|c|}
\hline & & $\mathrm{p}=\mathbf{0}$ & $\mathrm{p}=0.1$ & $\mathrm{p}=0.2$ & $p=0.3$ & $p=0.4$ & $\mathrm{p}=0.5$ & $\mathrm{p}=0.6$ & $p=0.7$ & $p=0.8$ & $p=0.9$ & $p=1$ \\
\hline \multirow[t]{9}{*}{ Argentina } & $\tau=0$ & 2.34 & 1.98 & 1.83 & 1.76 & 1.71 & 1.69 & 1.67 & 1.65 & 1.64 & 1.63 & 1.62 \\
\hline & $\tau=0.1$ & -- & 2.00 & 1.87 & 1.81 & 1.79 & 1.77 & 1.77 & 1.78 & 1.78 & 1.79 & 1.80 \\
\hline & $\tau=0.2$ & - & 2.02 & 1.91 & 1.87 & 1.86 & 1.87 & 1.89 & 1.92 & 1.95 & 1.99 & 2.03 \\
\hline & $\tau=0.3$ & -- & 2.04 & 1.95 & 1.93 & 1.95 & 1.98 & 2.03 & 2.09 & 2.16 & 2.23 & 2.32 \\
\hline & $\tau=0.4$ & -- & 2.07 & 1.99 & 2.00 & 2.04 & 2.11 & 2.19 & 2.29 & 2.41 & 2.55 & 2.71 \\
\hline & $\tau=0.5$ & -- & 2.09 & 2.03 & 2.07 & 2.14 & 2.25 & 2.38 & 2.54 & 2.73 & 2.96 & 3.25 \\
\hline & $\tau=0.6$ & -- & 2.11 & 2.08 & 2.14 & 2.25 & 2.41 & 2.60 & 2.85 & 3.15 & 3.54 & 4.06 \\
\hline & $\tau=0.7$ & -- & 2.13 & 2.13 & 2.22 & 2.38 & 2.59 & 2.87 & 3.24 & 3.73 & 4.41 & 5.41 \\
\hline & $\tau=0.8$ & -- & 2.16 & 2.18 & 2.31 & 2.52 & 2.81 & 3.20 & 3.75 & 4.55 & 5.82 & 8.12 \\
\hline \multirow[t]{9}{*}{ Brazil } & $\tau=0$ & 1.19 & 1.26 & 1.32 & 1.37 & 1.42 & 1.46 & 1.50 & 1.54 & 1.57 & 1.60 & 1.62 \\
\hline & $\tau=0.1$ & -- & 1.27 & 1.34 & 1.41 & 1.48 & 1.54 & 1.60 & 1.65 & 1.70 & 1.75 & 1.80 \\
\hline & $\tau=0.2$ & -- & 1.28 & 1.37 & 1.46 & 1.54 & 1.62 & 1.71 & 1.79 & 1.87 & 1.95 & 2.03 \\
\hline & $\tau=0.3$ & -- & 1.30 & 1.40 & 1.51 & 1.61 & 1.72 & 1.83 & 1.94 & 2.06 & 2.19 & 2.32 \\
\hline & $\tau=0.4$ & -- & 1.31 & 1.43 & 1.56 & 1.69 & 1.83 & 1.97 & 2.13 & 2.31 & 2.49 & 2.71 \\
\hline & $\tau=0.5$ & -- & 1.32 & 1.46 & 1.61 & 1.77 & 1.95 & 2.14 & 2.36 & 2.61 & 2.90 & 3.25 \\
\hline & $\tau=0.6$ & -- & 1.34 & 1.50 & 1.67 & 1.87 & 2.09 & 2.35 & 2.65 & 3.01 & 3.47 & 4.06 \\
\hline & $\tau=0.7$ & -- & 1.35 & 1.53 & 1.74 & 1.97 & 2.25 & 2.59 & 3.01 & 3.56 & 4.32 & 5.41 \\
\hline & $\tau=0.8$ & -- & 1.37 & 1.57 & 1.80 & 2.09 & 2.44 & 2.89 & 3.49 & 4.35 & 5.70 & 8.12 \\
\hline \multirow[t]{9}{*}{ Chile } & $\tau=0$ & 2.32 & 1.84 & 1.74 & 1.70 & 1.67 & 1.66 & 1.65 & 1.64 & 1.63 & 1.63 & 1.62 \\
\hline & $\tau=0.1$ & -- & 1.86 & 1.77 & 1.75 & 1.74 & 1.74 & 1.75 & 1.76 & 1.77 & 1.79 & 1.80 \\
\hline & $\tau=0.2$ & -- & 1.88 & 1.81 & 1.80 & 1.82 & 1.84 & 1.87 & 1.90 & 1.94 & 1.98 & 2.03 \\
\hline & $\tau=0.3$ & -- & 1.90 & 1.85 & 1.86 & 1.90 & 1.95 & 2.01 & 2.07 & 2.15 & 2.23 & 2.32 \\
\hline & $\tau=0.4$ & -- & 1.92 & 1.89 & 1.93 & 1.99 & 2.07 & 2.17 & 2.27 & 2.40 & 2.54 & 2.71 \\
\hline & $\tau=0.5$ & -- & 1.94 & 1.93 & 1.99 & 2.09 & 2.21 & 2.35 & 2.52 & 2.72 & 2.96 & 3.25 \\
\hline & $\tau=0.6$ & -- & 1.96 & 1.98 & 2.07 & 2.20 & 2.37 & 2.57 & 2.82 & 3.14 & 3.54 & 4.06 \\
\hline & $\boldsymbol{\tau}=\mathbf{0 . 7}$ & -- & 1.98 & 2.02 & 2.15 & 2.32 & 2.55 & 2.84 & 3.21 & 3.71 & 4.40 & 5.41 \\
\hline & $\tau=0.8$ & -- & 2.00 & 2.07 & 2.23 & 2.46 & 2.76 & 3.16 & 3.72 & 4.53 & 5.81 & 8.12 \\
\hline \multirow[t]{7}{*}{ Colombia } & $\tau=0$ & 1.90 & 1.71 & 1.67 & 1.65 & 1.64 & 1.64 & 1.63 & 1.63 & 1.63 & 1.62 & 1.62 \\
\hline & $\tau=0.1$ & -- & 1.73 & 1.70 & 1.70 & 1.71 & 1.72 & 1.74 & 1.75 & 1.77 & 1.79 & 1.80 \\
\hline & $\tau=0.2$ & -- & 1.75 & 1.74 & 1.76 & 1.79 & 1.82 & 1.86 & 1.89 & 1.94 & 1.98 & 2.03 \\
\hline & $\tau=0.3$ & -- & 1.76 & 1.78 & 1.82 & 1.87 & 1.93 & 1.99 & 2.06 & 2.14 & 2.23 & 2.32 \\
\hline & $\tau=0.4$ & -- & 1.78 & 1.82 & 1.88 & 1.96 & 2.05 & 2.15 & 2.26 & 2.39 & 2.54 & 2.71 \\
\hline & $\tau=0.5$ & -- & 1.80 & 1.86 & 1.94 & 2.05 & 2.18 & 2.33 & 2.51 & 2.71 & 2.95 & 3.25 \\
\hline & $\tau=0.6$ & -- & 1.82 & 1.90 & 2.02 & 2.16 & 2.34 & 2.55 & 2.81 & 3.13 & 3.53 & 4.06 \\
\hline
\end{tabular}




\begin{tabular}{|c|c|c|c|c|c|c|c|c|c|c|c|c|}
\hline & & $\mathrm{p}=\mathbf{0}$ & $\mathrm{p}=0.1$ & $\mathrm{p}=0.2$ & $\mathrm{p}=0.3$ & $\mathrm{p}=0.4$ & $\mathrm{p}=0.5$ & $\mathrm{p}=0.6$ & $p=0.7$ & $\mathrm{p}=0.8$ & $\mathrm{p}=0.9$ & $p=1$ \\
\hline & $\tau=0.7$ & -- & 1.84 & 1.94 & 2.09 & 2.28 & 2.52 & 2.81 & 3.19 & 3.70 & 4.39 & 5.41 \\
\hline & $\tau=0.8$ & -- & 1.86 & 1.99 & 2.17 & 2.42 & 2.73 & 3.14 & 3.70 & 4.52 & 5.80 & 8.12 \\
\hline \multirow[t]{9}{*}{ Mexico } & $\tau=0$ & 2.00 & 1.88 & 1.80 & 1.75 & 1.72 & 1.69 & 1.67 & 1.66 & 1.64 & 1.63 & 1.62 \\
\hline & $\tau=0.1$ & -- & 1.90 & 1.84 & 1.81 & 1.79 & 1.78 & 1.78 & 1.78 & 1.79 & 1.79 & 1.80 \\
\hline & $\tau=0.2$ & -- & 1.92 & 1.88 & 1.86 & 1.87 & 1.88 & 1.90 & 1.93 & 1.96 & 1.99 & 2.03 \\
\hline & $\tau=0.3$ & -- & 1.94 & 1.92 & 1.93 & 1.95 & 1.99 & 2.04 & 2.10 & 2.16 & 2.24 & 2.32 \\
\hline & $\tau=0.4$ & -- & 1.96 & 1.96 & 1.99 & 2.04 & 2.11 & 2.20 & 2.30 & 2.42 & 2.55 & 2.71 \\
\hline & $\tau=0.5$ & -- & 1.98 & 2.00 & 2.06 & 2.15 & 2.26 & 2.39 & 2.55 & 2.74 & 2.97 & 3.25 \\
\hline & $\tau=0.6$ & -- & 2.00 & 2.05 & 2.14 & 2.26 & 2.42 & 2.61 & 2.86 & 3.16 & 3.55 & 4.06 \\
\hline & $\tau=0.7$ & -- & 2.02 & 2.10 & 2.22 & 2.39 & 2.60 & 2.88 & 3.25 & 3.73 & 4.41 & 5.41 \\
\hline & $\tau=0.8$ & -- & 2.04 & 2.15 & 2.31 & 2.53 & 2.82 & 3.21 & 3.76 & 4.56 & 5.83 & 8.12 \\
\hline \multirow[t]{9}{*}{ Peru } & $\tau=0$ & 1.34 & 1.50 & 1.55 & 1.58 & 1.59 & 1.60 & 1.61 & 1.61 & 1.62 & 1.62 & 1.62 \\
\hline & $\tau=0.1$ & -- & 1.52 & 1.59 & 1.63 & 1.66 & 1.69 & 1.71 & 1.74 & 1.76 & 1.78 & 1.80 \\
\hline & $\tau=0.2$ & -- & 1.54 & 1.62 & 1.68 & 1.73 & 1.78 & 1.83 & 1.88 & 1.93 & 1.98 & 2.03 \\
\hline & $\tau=0.3$ & -- & 1.55 & 1.65 & 1.73 & 1.81 & 1.89 & 1.96 & 2.04 & 2.13 & 2.22 & 2.32 \\
\hline & $\tau=0.4$ & -- & 1.57 & 1.69 & 1.79 & 1.90 & 2.00 & 2.12 & 2.24 & 2.38 & 2.53 & 2.71 \\
\hline & $\tau=0.5$ & -- & 1.58 & 1.73 & 1.86 & 1.99 & 2.14 & 2.30 & 2.48 & 2.70 & 2.95 & 3.25 \\
\hline & $\tau=0.6$ & -- & 1.60 & 1.77 & 1.93 & 2.10 & 2.29 & 2.51 & 2.78 & 3.11 & 3.52 & 4.06 \\
\hline & $\tau=0.7$ & -- & 1.62 & 1.81 & 2.00 & 2.21 & 2.47 & 2.77 & 3.16 & 3.68 & 4.38 & 5.41 \\
\hline & $\tau=0.8$ & -- & 1.64 & 1.85 & 2.08 & 2.34 & 2.67 & 3.09 & 3.67 & 4.49 & 5.79 & 8.12 \\
\hline \multirow[t]{9}{*}{ Venezuela } & $\tau=0$ & 2.25 & 2.29 & 1.94 & 1.81 & 1.74 & 1.70 & 1.68 & 1.66 & 1.64 & 1.63 & 1.62 \\
\hline & $\tau=0.1$ & -- & 2.31 & 1.98 & 1.86 & 1.82 & 1.79 & 1.78 & 1.78 & 1.79 & 1.79 & 1.80 \\
\hline & $\tau=0.2$ & -- & 2.33 & 2.02 & 1.92 & 1.89 & 1.89 & 1.91 & 1.93 & 1.96 & 1.99 & 2.03 \\
\hline & $\tau=0.3$ & -- & 2.36 & 2.06 & 1.99 & 1.98 & 2.00 & 2.04 & 2.10 & 2.16 & 2.24 & 2.32 \\
\hline & $\tau=0.4$ & -- & 2.38 & 2.11 & 2.06 & 2.08 & 2.13 & 2.21 & 2.30 & 2.42 & 2.55 & 2.71 \\
\hline & $\tau=0.5$ & -- & 2.41 & 2.15 & 2.13 & 2.18 & 2.27 & 2.40 & 2.55 & 2.74 & 2.97 & 3.25 \\
\hline & $\tau=0.6$ & -- & 2.43 & 2.20 & 2.21 & 2.29 & 2.43 & 2.62 & 2.86 & 3.16 & 3.55 & 4.06 \\
\hline & $\tau=0.7$ & -- & 2.46 & 2.25 & 2.29 & 2.42 & 2.62 & 2.89 & 3.25 & 3.74 & 4.41 & 5.41 \\
\hline & $\tau=0.8$ & -- & 2.49 & 2.31 & 2.38 & 2.56 & 2.84 & 3.22 & 3.77 & 4.57 & 5.83 & 8.12 \\
\hline
\end{tabular}

(Note) Shaded cells capture those situations under which the coverage ratio is improved relative to the nonpooling baseline. 